\title{
Effect of bisphenol-A on the structures and properties of phthalonitrile-based resin containing benzoxazine
}

\author{
M. Z. Xu* , K. Jia, X. B. Liu \\ Research Branch of Functional Materials, Institute of Microelectronic \& Solid State Electronic, High-Temperature \\ Resistant Polymers and Composites Key Laboratory of Sichuan Province, University of Electronic Science and \\ Technology of China, 610054 Chengdu, P. R. China
}

Received 4 November 2014; accepted in revised form 2 January 2015

\begin{abstract}
Phthalonitrile and benzoxazine have been considered as high-performance materials in the field of heterocyclic chemistry. The polymerization of phthalonitrile and benzoxazine accelerated by active phenolic hydroxyl has attracted wide interests. In this work, self-promoted polymerization behavior and processability of phthalonitrile containing benzoxazine (BA-ph) with bisphenol-A (BPA) were investigated. Results revealed that BA-ph/BPA exhibited representative doublestage curing behaviors corresponding to the ring-opening polymerization of benzoxazine rings and ring-formation polymerization of nitrile groups. Compared with that of BA-ph, processability of BA-ph/BPA was improved and could be tuned by varying BPA contents, processing temperature and time. Then BA-ph/BPA/glass fiber (GF) composite laminates were prepared. In comparison with that of BA-ph/GF laminates (542 MPa and $25.8 \mathrm{GPa}$ ), the flexural strength and modulus were up to $789 \mathrm{MPa}$ and $23.6 \mathrm{GPa}$, respectively. Moreover, double $T_{\mathrm{g}} \mathrm{s}$ were observed at temperature around $200 \sim 300^{\circ} \mathrm{C}$ and $300 \sim 380^{\circ} \mathrm{C}$, indicating microphase separation during the polymerization of oxazine rings and nitrile groups, confirmed by the scanning electron microscopic (SEM) images. Thermal stabilities demonstrated that all BA-ph/BPA/GF composites exhibited high $T_{10 \%}$ up to $510^{\circ} \mathrm{C}$. The systematic study of BA-ph/BPA system could enrich our knowledge on phthalonitrile-based resins in industrial applications, especially in the areas which require excellent mechanical properties and high temperature resistance.
\end{abstract}

Keywords: polymer composites, phthalonitrile, benzoxazine, interpenetrating network, cross-linking

\section{Introduction}

Over the past decades, epoxy (EP), phenolic (PE) and benzoxazine $(\mathrm{Bz})$ resins have been reported widely in the fabrication of GF-reinforced laminates due to their properties such as good wettability, nice processability and good chemical resistances [1-3]. While the common thermal properties $\left(150 \sim 300^{\circ} \mathrm{C}\right)$ and low glass transition temperature $\left(100 \sim 250^{\circ} \mathrm{C}\right)$ of the polymers have greatly limited their further applications in the fields of marine, aerospace and electronic packaging $[3,4]$. As the only candidate to satisfy the flame standards of United States Navy (MIL-STD-2031), phthalonitrile resins have attracted increased attentions both in laboratory and industry areas, recently. However, high curing temperature $\left(\geq 250^{\circ} \mathrm{C}\right)$, high postcuring temperature $\left(\geq 375^{\circ} \mathrm{C}\right)$ and narrow processing window $\left(\leq 30^{\circ} \mathrm{C}\right)$ have also greatly limited their wide applications $[5,6]$. To solve these problems, phthalonitrile-based monomers with additional polymerisable groups such as amino, carboxyl, propargyl, oxazine, allyl, etc. were designed and synthesized to pursue self-promoted polymerization and a broad processing window for advanced applications [7-11].

It is well known that a simple and effective method is the incorporation of hydroxyl or amino groups

\footnotetext{
${ }^{*}$ Corresponding author, e-mail: lisa735994712@126.com

(C) BME-PT
} 
into the reactive phthalonitrile units. The hydroxyor amino-functional phthalonitrile polymers were proved to cross-link by self-promoted curing [12, 13]. A kind of phthalonitrile containing benzoxazine resin (BA-ph) was designed and synthesized via a condensation reaction between amino-functional phthalonitrile and bisphenol A, shown in Figure 1 [14]. Owing to the active phenolic hydroxyls generated from ring-opening of benzoxazine, many advantages can be obtained. On the one hand, the active phenolic hydroxyls generated from ring-opening of benzoxazine can be used as a kind of curing agent to achieve the cross-linking networks, thus realizing the self-promoted copolymerization. On the other hand, the active phenolic hydroxyls allowed BA-ph to be used as hydroxyl-functional phthalonitrile to achieve good processability and desirable properties of the composites [14-16]. In addition, the initial curing temperature and postcuring temperature of BA-ph were $200 \sim 220$ and $280^{\circ} \mathrm{C}$, respectively, which significantly improved the processibility of phthalonitrile-based resins. However, the process temperatures were also quite high for the industry applications which required the composites fabricated in lower temperature $\left(\leq 200^{\circ} \mathrm{C}\right)$. Additionally, it was obvious that the outstanding properties of phthalonitrile-based composites were attributed to the completed polymerization of nitrile groups. Previous reports indicated that a mass of nitrile groups remaining in the polymer composites. Thus, the properties of BA-ph polymers can be further improved via increasing the polymerization degree of nitrile groups.

The mechanism for benzoxazine ring curing involves ring opening by protonation of the oxygen atom to form an iminium ion and active hydroxy merits, then electrophilic aromatic substitution, which was earlier established by McDonagh and Smith that 3, 4-dihydro-2H-1, 3-benzoxazines exhibit ring/chain tautomerism when protonated by migration of the proton from the nitrogen to the oxygen atom [17]. Meanwhile, the phthalonitrile-based resins can be effectively catalyzed by the active hydroxyl to form phthalocyanine-dominated polymers. In terms of the given mechanism, bisphenol-A (BPA) was introduced in the BA-ph matrix which provided additional active hydroxyl.

In this study, to understand the catalysis behaviors of active hydroxy in the curing process of BA-ph resin, various molar ratios BPA were introduced. Curing behaviors and processability of BA-ph/BPA were investigated by differential scanning calorimetric (DSC) and dynamic rheological analysis (DRA). The structural transition of the BA-ph/BPA system in the polymerization process was observed by Fourier transform infrared spectrometer (FTIR) and scanning electron microscope (SEM) images. The possible reaction process between BA-ph and BPA was presented in Figures 2 and 3. Then, solution prepolymer method was employed to prepare the impregnating adhesive and GF-reinforced laminates were fabricated by heat compression molding at $160^{\circ} \mathrm{C}$. The mechanical and thermal measurements have been performed to evaluate the effects of BPA on the composite laminates. Also, the significant enhancements of the mechanical properties for BA-ph/BPA/GF laminates have been discussed.

\section{Experimental}

\subsection{Materials}

Bisphenol-A, paraformaldehyde, 1, 4-dioxane, and toluene were obtained from Tianjin BODI Chemicals Co. Ltd., Tianjin, China. 4-Nitrophthalonitrile was obtained from Alpha Chemical (Dezhou) Co. Ltd., Shijiazhuang, China. Butanone was purchased from Tianjin Guangfu Fine Chemical Research Institute. 3-Aminophenoxyphthalonitrile (3-APN, $T_{\mathrm{m}}=174^{\circ} \mathrm{C}$ ) was obtained from Dymatic Special Chemicals co., ltd., Chengdu, China. The woven glass fiber fabric is E-glass cloth-7628 provided by Jiangxi Changjia

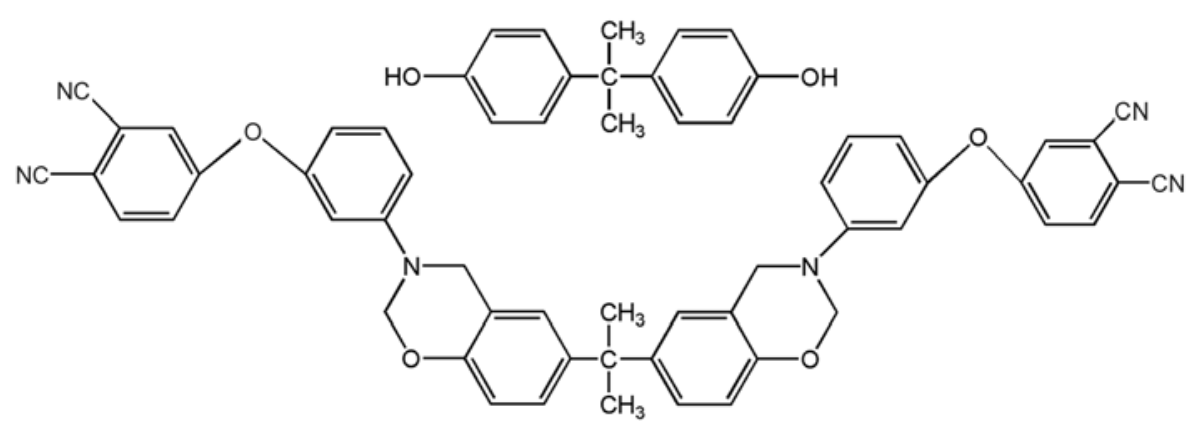

Figure 1. Structures of BPA and BA-ph monomer 


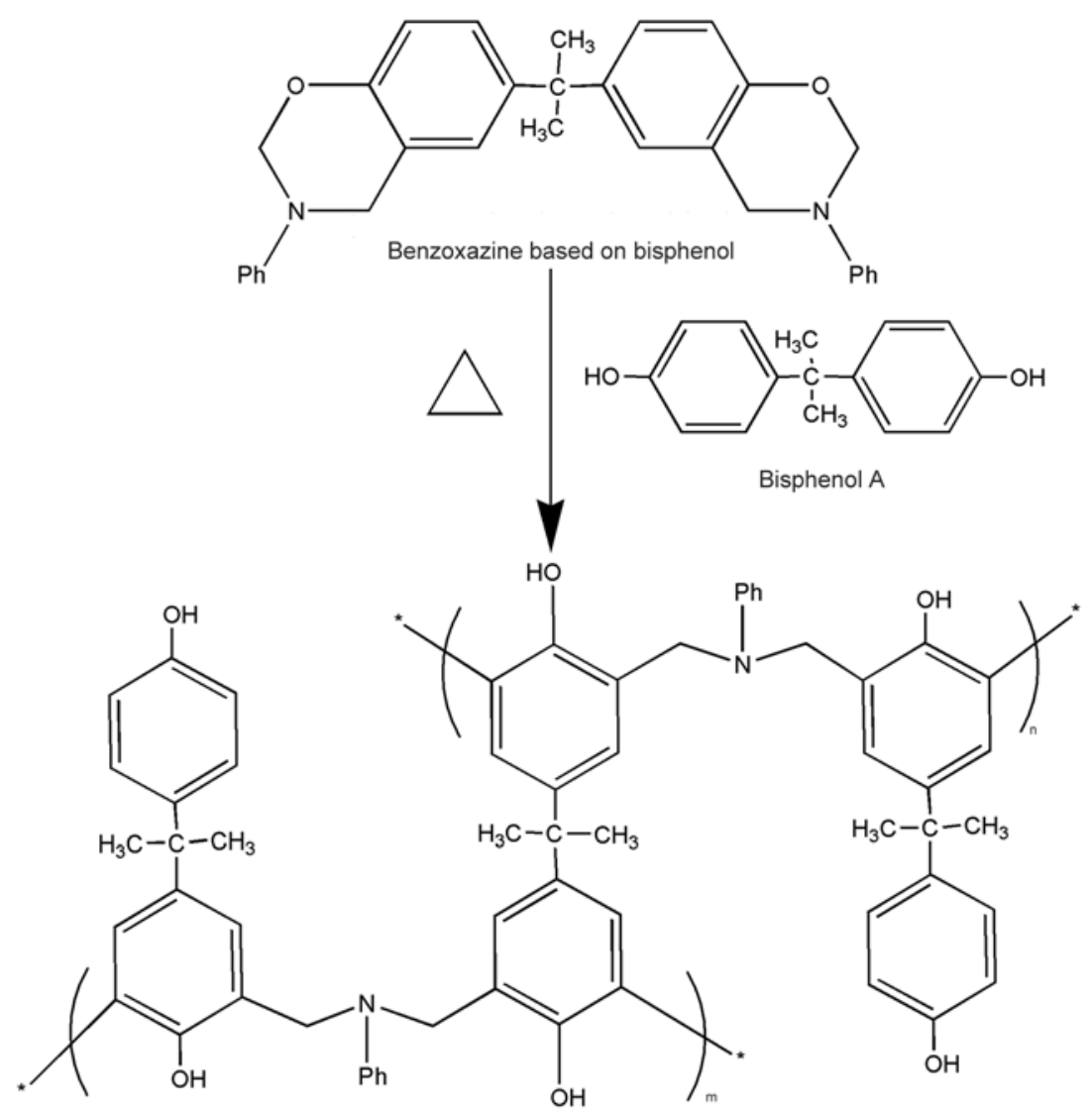

Figure 2. Reaction scheme for the AB-crosslinked polymerization of benzoxazine and BPA

glass fiber Co. Ltd., Jiangxi, China. The thickness of the fiber cloth was $0.188 \mathrm{~mm}$ and the weight was $210 \mathrm{~g} / \mathrm{m}^{2}$. All the reagents were of analytical grade and used without further purification.

\subsection{Synthesis of phthalonitrile containing benzoxazine (BA-ph)}

The synthetic route of BA-ph monomer was synthesized according to the reference $[14,18]$ reported before with minor modifications. In a typical experiment, 3-APN (47.00 g, $0.20 \mathrm{~mol})$, bisphenol-A $(22.80 \mathrm{~g}, 0.10 \mathrm{~mol})$, paraformaldehyde $(12.00 \mathrm{~g}$, $0.40 \mathrm{~mol})$ and 1,4 -Dioxane $(60 \mathrm{~mL})$ and toluene $(10 \mathrm{~mL})$ were mixed under a stirrer at a speed of $300 \mathrm{rpm}$. After being refluxed at $100^{\circ} \mathrm{C}$ for $5 \mathrm{~h}$, the reaction mixture was treated by rotary evaporation processing. Then, the mixture completely dissolved in chloroform to remove the benzoxazine oligomer. Finally, the solution was slowly poured into the alkaline solution of sodium hydroxide $\left(0.5 \mathrm{~mol} \cdot \mathrm{L}^{-1}\right)$ distilled water to remove the bisphenol-A residue and cooled to room temperature in the formation of a solid. The solid was filtered and washed five times with distilled water. Then the yellow solid was dried in a vacuum at $60^{\circ} \mathrm{C}$ overnight.

\subsection{Preparation of BA-ph/BPA blends and impregnating adhesive}

The BA-ph/BPA thermosetting blends with various molar ratios (BA-ph/BPA ratios: 2:1, 2:2, and 2:3) were prepared by physical blending at room temperature $\left(25^{\circ} \mathrm{C}\right)$, labeled as BA-ph/BPA21, BA-ph/ BPA22 and BA-ph/BPA23, respectively. As a reference, the pure BA-ph was prepared similarly.

The BA-ph/BPA impregnating adhesive with various content of BPA was prepared by solution prepolymer method in butanone at $80^{\circ} \mathrm{C}$ for $2 \mathrm{~h}$. Then, the viscous solution was obtained.

\subsection{Preparation of BA-ph/BPA/GF composite laminates}

The preparation of the BA-ph/BPA/GF composite laminates was carried out as follows. GF cloth $\left(20 \times 20 \mathrm{~cm}^{2}\right)$ was brush-coated with the viscous solution obtained above and dried at room temperature for $24 \mathrm{~h}$. The ratio was designed to give a prepreg of $40 \%$ copolymers and $60 \%$ GF by weight. Ten layers of GF prepreg cloth were placed in a stainless steel mold and hot-pressed under a pressure of $20 \mathrm{MPa}$ at $160^{\circ} \mathrm{C}$ for $4 \mathrm{~h}$. The laminates were natural cooled to room temperature and then solid poly- 


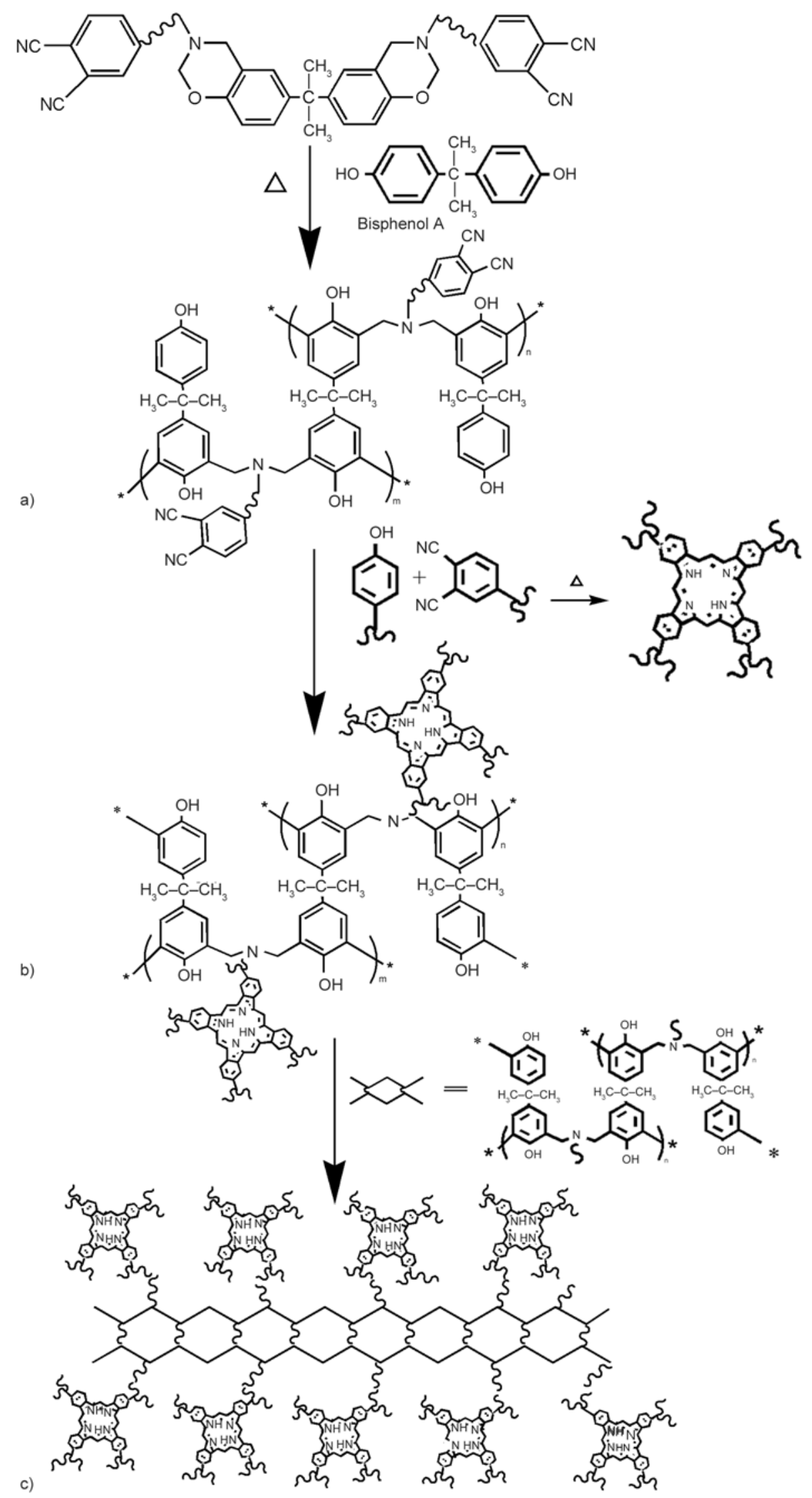

Figure 3. Reaction scheme for the polymerization of BA-ph: (a) linear linked of benoxazine, (b) ring-forming polymerization of nitrile groups and (c) possible structures of resultant polymers 
merized at $200^{\circ} \mathrm{C}$ for $4 \mathrm{~h}, 240^{\circ} \mathrm{C}$ for $2 \mathrm{~h}$ and $280^{\circ} \mathrm{C}$ for $2 \mathrm{~h}$ in the oven, respectively. The final laminates were marked as BA-ph/BPA/GF21, BA-ph/BPA/ GF22 and BA-ph/BPA/GF23, respectively.

\subsection{Characterizations}

Differential scanning calorimetric (DSC) analysis was performed by TA Instruments Modulated DSCQ100 at a heating rate of $10^{\circ} \mathrm{C} / \mathrm{min}$ and a nitrogen flow rate of $50 \mathrm{~mL} / \mathrm{min}$. The second DSC scans were performed for the according samples. Dynamic rheological analysis (DRA) was performed using TA Instruments Rheometer AR-G2 with a frequency of $1 \mathrm{~Hz}$ at different temperatures in air. The samples (0.5-1 g) were melted between $25 \mathrm{~mm}$ diameter parallel plates with an environmental testing chamber of the rheometer. FTIR spectra were recorded with Shimadzu FTIR8400S Fourier Transform Infrared spectrometer in $\mathrm{KBr}$ pellets between 4000 and $500 \mathrm{~cm}^{-1}$ in air. The flexural tests of the composite laminates were performed with a SANS CMT6104 series desktop electromechanical universal testing machine at room temperature. Flexural tests (three-point bending mode) were held according to the GB/T9341-2008 standard test method with a crosshead displacement speed of $10 \mathrm{~mm} / \mathrm{min}$ and the test fixture was mounted in a $10 \mathrm{kN}$ capacity. The samples (dimension: $80 \mathrm{~mm}$ $\times 15 \mathrm{~mm} \times 2 \mathrm{~mm}$ ) were tested with a support span/ sample thickness ratio of 15:1, and gained as average value for every three samples. Dynamic mechanical analysis (DMA) in a three-point-blending mode was performed on QDMA-800 dynamic mechanical analyzer (TA Instruments, USA) to determine the glass transition temperature $\left(T_{\mathrm{g}}\right)$. The storage modulus and tan delta were investigated at a frequency of $1 \mathrm{~Hz}$ and amplitude of $20 \mu \mathrm{m}$, and the samples (dimensions $30 \mathrm{~mm} \times 10 \mathrm{~mm} \times 2 \mathrm{~mm}$ ) were heated from 50 to $400^{\circ} \mathrm{C}$ at a temperature ramp of $3^{\circ} \mathrm{C} / \mathrm{min}$. Thermal gravimetric analysis (TGA) was performed on a TA Instruments TGA Q50 with a heating rate of $20^{\circ} \mathrm{C} / \mathrm{min}$ (under nitrogen or air) and a purge of $40 \mathrm{~mL} / \mathrm{min}$. The morphology of the fractured surfaces of the polymers were observed by SEM (JSM2 $5900 \mathrm{LV}$ ) operating at $20 \mathrm{kV}$.

\section{Results and discussion}

\subsection{Curing behaviors of BA-ph/BPA blends}

Model curing studies were conducted to character the curing behavior of phthalonitrile monomer with the curing agent of 2-hydroxydiphenylmethane [19]. Compounds with phenol hydroxyl were used as nucleophilic initiator to catalyze the reaction between nitrile groups of phthalonitrile monomer. This was driven by the fact that the nitrile groups can readily form the isoindoline, diimino, triazine and phthalocyanine with nucleophilic phenol groups [20].

The curing behaviors of BA-ph/BPA blends were studied by DSC analysis presented in Figure 4 and the main data were shown in Table 1. The typical curves of BA-ph and BPA monomer were shown in Figure $4 \mathrm{~b}$. It can be seen that the poignant endothermic transition observed at $156^{\circ} \mathrm{C}$ was assigned to the melting temperature ( $\left.T_{\text {melt }}\right)$ of BPA monomer. However, the wide endothermic transition started from $200^{\circ} \mathrm{C}$ and peaked at $250^{\circ} \mathrm{C}$ was attributed to the evaporation of BPA monomer. In Figure $4 \mathrm{~b}$ (curve a) for pristine BA-ph, the double exotherm bands were peaked at $230^{\circ} \mathrm{C}$ and $263^{\circ} \mathrm{C}$, corresponding to the ring-opening polymerization of oxaznine rings and the ring-forming polymerization of nitrile groups, respectively $[14,15]$. With the introduction of BPA, the exotherm bands shifted to a
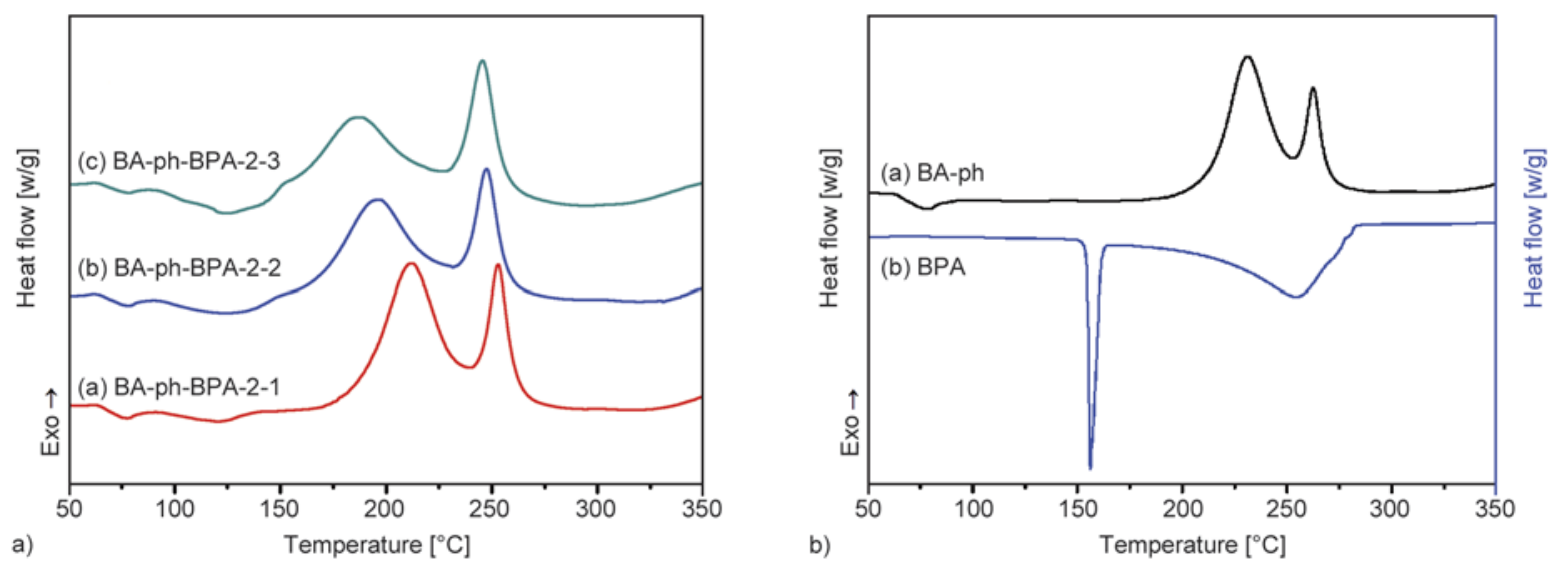

Figure 4. DSC curves of (a): BA-ph/BPA blends with various contents of BPA and (b): BA-ph and BPA monomers 
Table 1. Thermal properties of BA-ph/BPA system

\begin{tabular}{|c|c|c|c|c|c|c|c|}
\hline Samples & $\begin{array}{c}\mathbf{T}_{\mathbf{m}} \\
{\left[{ }^{\circ} \mathbf{C}\right]}\end{array}$ & $\begin{array}{c}\mathbf{T}_{\mathbf{i}} \\
{\left[{ }^{\circ} \mathbf{C}\right]}\end{array}$ & $\begin{array}{l}\mathrm{T}_{\text {top }_{1}} \\
{\left[{ }^{\circ} \mathrm{C}\right]}\end{array}$ & $\begin{array}{l}\mathbf{T}_{\text {top }_{2}} \\
{\left[{ }^{\circ} \mathbf{C}\right]}\end{array}$ & $\begin{array}{c}\Delta \mathbf{H}_{\text {curing }_{1}} \\
{[\mathrm{~J} / \mathrm{g}]}\end{array}$ & $\begin{array}{c}\Delta \mathbf{H}_{\text {curing }_{2}} \\
{[\mathrm{~J} / \mathrm{g}]}\end{array}$ & $\begin{array}{c}\text { Weight loss } \\
{[\%]}\end{array}$ \\
\hline BPA & 156 & - & - & - & - & - & 100 \\
\hline BA-ph & 56.5 & 170 & 230 & 263 & 167.7 & 46.1 & 0.48 \\
\hline BA-ph-BPA21 & 79.2 & 125 & 210 & 253 & 201.5 & 69.3 & 1.86 \\
\hline BA-ph-BPA22 & 78.5 & 126 & 193 & 248 & 178.1 & 76.6 & 3.95 \\
\hline BA-ph-BPA23 & 77.8 & 123 & 183 & 246 & 172.8 & 98.3 & 9.65 \\
\hline
\end{tabular}

lower temperature range, shown in Figure 4a. The peak temperatures of BA-ph/BPA systems were lowered to $183 \sim 210^{\circ} \mathrm{C}$ and the maximum was lowered to $246 \sim 253^{\circ} \mathrm{C}$. The lowering of the temperature necessary for the ring-opening polymerization of BA-ph has considerable meaning because the high temperature necessary for the complete polymerization often cause problems and limits its applications. Additionally, the enthalpy of curing of BAph/BPA blends was different in comparison with that of pristine BA-ph, both for the ring-opening of oxazine rings and ring-forming of nitrile groups. The enthalpy for the ring-opening of oxazine rings successively decreased with increasing the BPA, shown in Table 1. It was related to the fact that the oxazine rings formed more easily Mannich bridge structures in the presence of phenol hydroxyl. References reported that the phenolic compounds with free ortho or para positions act as initiators for the ring-opening oligomerization of benzoxazine composites, and an aminoalkylation reaction occur preferentially at the ortho and para positions of phenols [20-23]. Thus, the phenol hydroxyl groups in BPA help the ring-opening reaction of oxazine rings through copolymerization with BA-ph, affording an AB-crosslinked polymer, shown in Figure 2.

Moreover, the initial curing temperature gradient between oxazine rings and nitrile groups has been enlarged with increasing the content of BPA, shown in Figure $4 \mathrm{a}$. The difference of polymerization rate would result in a microphase separation between the components resulting from the polymerization of oxazine rings and nitrile groups, respectively. As shown in Figure 3, BPA firstly catalyzed the ringopening polymerization of oxazine rings and the linear polybenzoxazine formed (Figure 3a). Then, the ring-forming polymerization of nitrile groups was triggered by the active hydroxyl provided both from the oxazine rings and BPA (Figure 3b). With increasing the temperature or prolonging the time, the phthalocyanine cycles self-aggregated and par- alleled to the linear linked network of polybenzoxazine (Figure 3c).

To further study the curing behaviors of BA-ph/ BPA blends, isothermal DSC curves as a function of time have also been investigated at $180^{\circ} \mathrm{C}$. It can be seen in Figure 5 (curve a) that there was a weak and wide exothermic band appeared at about $15 \mathrm{~min}$, which indicated the extremely low curing rate of pristine BA-ph at $180^{\circ} \mathrm{C}$. Figure 5 (curve $b$ and c) and (curve d) showed the curves of BA-ph/BPA blends with various contents of BPA. All the blends exhibited double exothermic peaks which resulted from the double curing reactions. For all of the blends, the first exothermic peaks occurred quickly at about 0.5 20 min and the second occurred at 30 60 min. As can be seen, with increasing the content of BPA, the intensity of the first exothermic peak increased significantly. The reason was that the ring-opening reaction reinforced by BPA monomer and the formation of the Mannich bridge structures via ringopening polymerization was the first priority [11, $14,16]$. The second exothermic peak corresponded to the polymerization of nitrile groups catalyzed by the extra hydrogen provided from the ring-opening of oxazine rings and BPA. For the curve of BA-

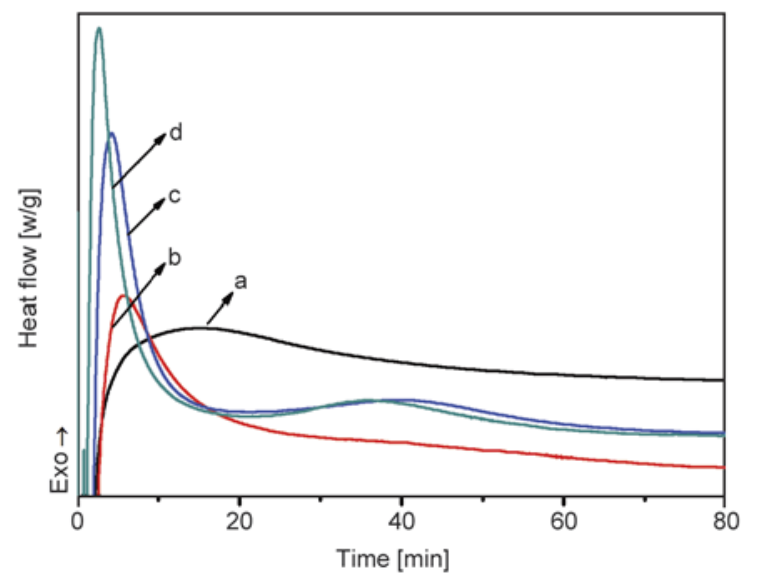

Figure 5. Time sweep DSC curves of BA-ph/BPA blends with various content of BPA: (a) BA-ph, (b) BAph/BPA21, (c) BA-ph/BPA22 and (d) BA-ph/ BPA23 
ph/BPA22 system, the second exothermic peak related to the polymerization of nitrile groups was proportional in comparison with that of BA$\mathrm{ph} / \mathrm{BPA} 23$ and stronger obviously than that of BAph/BPA21. In all, the polymerization of BA-ph could be significantly catalyzed by BPA and polymerization of the blends could be easily triggered at lower temperatures and controlled by varying the content of BPA. Additionally, with increasing the content of BA-ph, curing temperature gradient between oxazine rings and nitrile groups has been explicated.

\subsection{Processability of BA-ph/BPA blends}

The rheological behavior, a key factor in predicting processability, was studied by measuring viscosity changes accompanying the self-promoted curing reaction of the BA-ph/BPA blends. In Figure 6, the complex viscosity $\left(\eta^{*}\right)$ of BA-ph/BPA blends, as well as that of BA-ph, was determined as a function of temperature from 50 to $300^{\circ} \mathrm{C}$. In each case, a decrease was observed in viscosity and a minimum melt viscosity of 1-6 $\mathrm{Pa} \cdot \mathrm{s}$ was observed for the blends. The low viscosity was maintained in the temperature range from $80 \sim 180^{\circ} \mathrm{C}$, suggesting good processability of BA-ph/BPA systems. A rapid increase of $\eta^{*}$ was observed at about $180 \sim 200^{\circ} \mathrm{C}$ for all BA-ph/BPA blends. Moreover, the increase of $\eta^{*}$ was observed at lower temperatures with increasing the amount of BPA.

To further determine the processing temperature and time for BA-ph/BPA blends, the $\eta^{*}$ change of the BA-ph/BPA22 blend was measured as a function of time at various temperatures, shown in Fig-

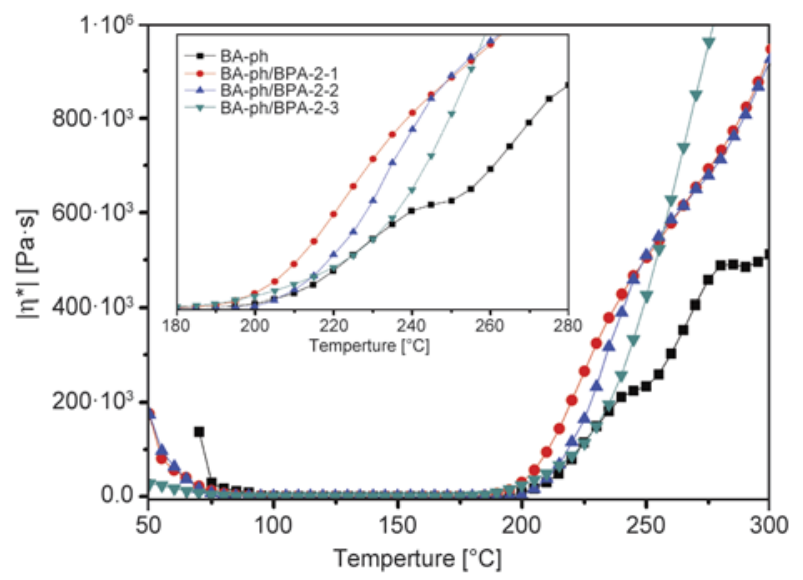

Figure 6. Complex viscosity $\left(\eta^{*}\right)$ as a function of temperature for BA-ph/BPA system with various content of BPA

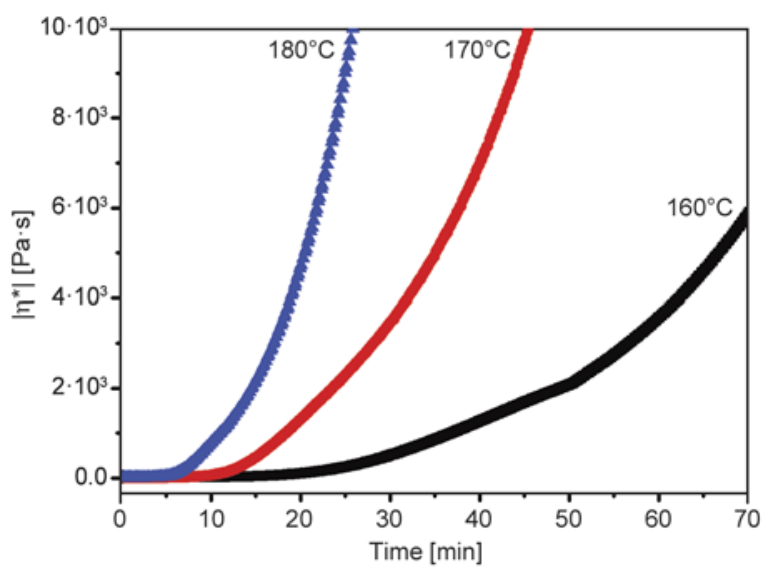

Figure 7. Complex viscosity $\left(\eta^{*}\right)$ as a function of time at various temperatures for the BA-ph/BPA22 system

ure 7. The curves indicated that the viscosity increased with the increase of temperature. As expected, high temperature had a great tendency to accelerate the polymerization reaction of BA-ph/ BPA blends. It can be seen that the $\eta^{*}$ at different temperatures were relatively low and stable before the final curing reaction occurred. However, after the curing reaction started, the $\eta^{*}$ increased dramatically [24]. Namely, the increase of $\eta^{*}$ for BA-ph/ BPA22 blend at 170 and $180^{\circ} \mathrm{C}$ took a rather short time (12 and $6 \mathrm{~min}$ ), revealing that curing reaction carried out rapidly. Thus, $160^{\circ} \mathrm{C}$ was a proper processing temperature for BA-ph/BPA copolymers.

For comparison, isothermal viscosity measurements were recorded on the BA-ph/BPA blends at $160^{\circ} \mathrm{C}$ as a function of time to investigate the effect of BPA content on the processability. As depicted in Figure 8, it can be seen that all of the BA-ph/BPA blends exhibited relatively low initial $\eta^{*}$ and the initial $\eta^{*}$

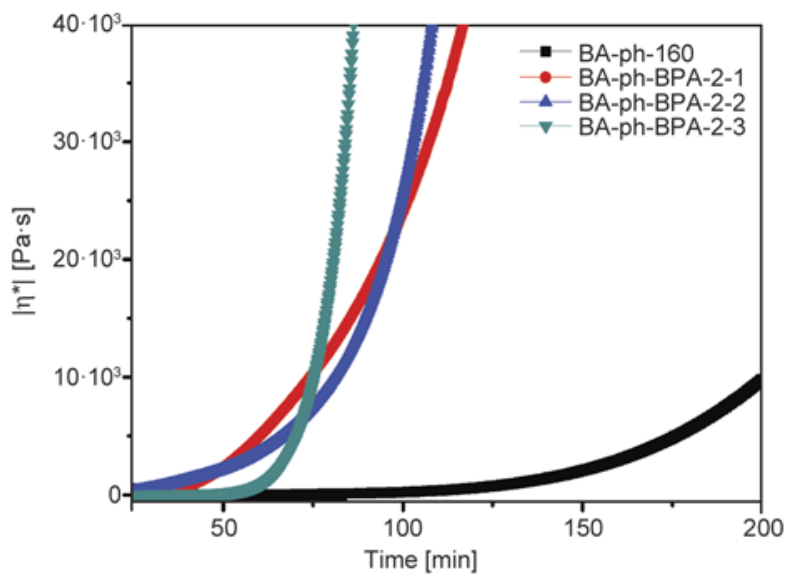

Figure 8. Complex viscosity $\left(\eta^{*}\right)$ as a function of time at $160^{\circ} \mathrm{C}$ for the BA-ph/BPA system with various content of BPA 
of BA-ph/BPA blends decreased with increasing the amount of BPA. A complex melt viscosity around $3 \mathrm{~Pa} \cdot \mathrm{s}$ was observed for all of the blends at $160^{\circ} \mathrm{C}$, initially, and then exhibited a dramatic increasing viscosity. The complex viscosity of BA-ph/BPA21, BA-ph/BPA22 and BA-ph/BPA23 blends increased to $5000 \mathrm{~Pa} \cdot \mathrm{s}$ in about 57,64 and $70 \mathrm{~min}$, respectively. Moreover, BA-ph/BPA21, BA-ph/BPA22 and BA-ph/BPA23 blends show different modes with the extension of testing time. The complex viscosity increased rapidly until the complex viscosity of BA$\mathrm{ph} / \mathrm{BPA}$ was $12000 \mathrm{~Pa} \cdot \mathrm{s}$. Then, the increasing trend of complex viscosity was coincident with the increasing content of BPA. The sectionalized increasing of complex viscosity suggested the double-stage polymerization attributed to the ring-opening polymerization of oxazine rings and the ring-forming polymerization of nitrile groups accelerated by hydroxyl provided by BPA and ring-opening of oxazine rings at elevated temperature. These were in good agreement with the results of DSC. In all, results revealed that the influence of BPA content on the rate of the copolymerization was evident and the blends had the desirable processing temperature and gelation time [25]. Based on these rheological results, the blends exhibited the desirable polymerization rate and a wide processing window, which are important to their applications in resin transfer molding or resin infusion processes.

\subsection{Structures of BA-ph/BPA pre-polymers and polymers}

To confirm the structural transition of the composites, the structures of BA-ph/BPA pre-polymers obtained after being heated at $160^{\circ} \mathrm{C}$ and $\mathrm{BA}-\mathrm{ph} /$ BPA22 polymers heated at 200,240 and $280^{\circ} \mathrm{C}$ were investigated by FTIR spectra, respectively, as shown in Figure 9 and Figure 10. In Figure 9, the intensity characteristic absorption band at $1478 \mathrm{~cm}^{-1}$ was assigned to the in-plane $\mathrm{C}-\mathrm{H}$ stretching of the tetra-substituted benzene, indicating that the methylene bridges formed in the free ortho positions of the phenolic structures [26, 27]. Meanwhile, the characteristic band of oxazine at around $967 \mathrm{~cm}^{-1}$ did not appear in the spectra, confirming oxazine rings were involved into the polymerization at $160^{\circ} \mathrm{C}$. Meanwhile, the peaks observed at 1164 and $1114 \mathrm{~cm}^{-1}$ were corresponded to the frame vibration of phthalocyanine, and peaks at 1620 and $1283 \mathrm{~cm}^{-1}$ were assigned to the stretching vibration

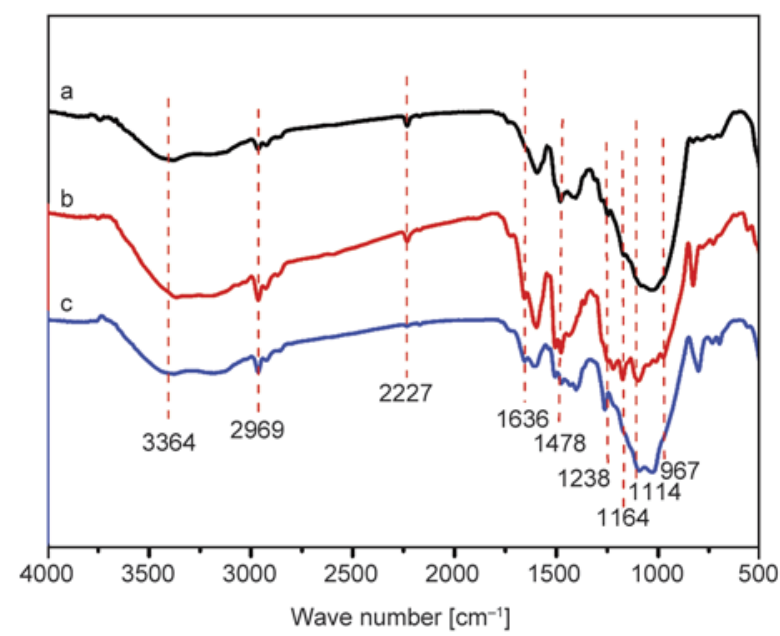

Figure 9. FTIR spectra of BA-ph/BPA system with various content of BPA heat treated at $160^{\circ} \mathrm{C}$ : (a) BA-ph/ BPA21, (b) BA-ph/BPA22 and (c) BA-ph/BPA23

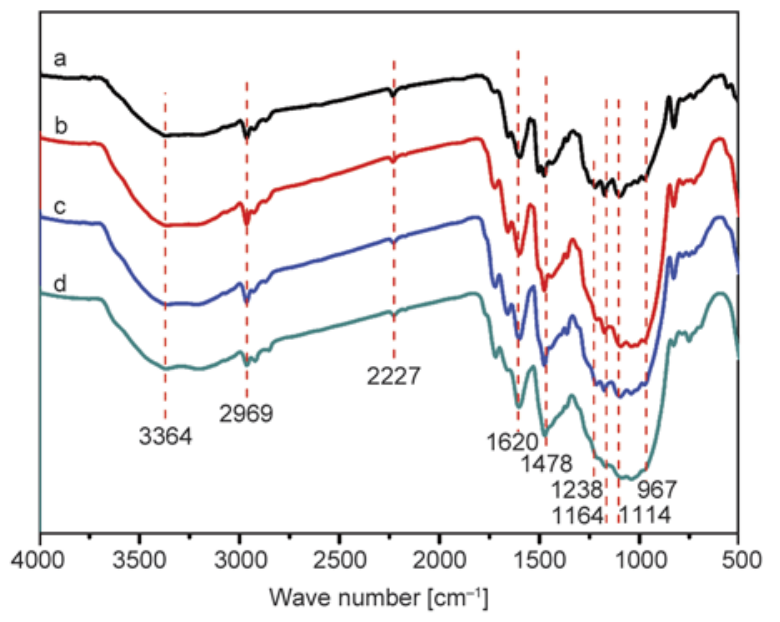

Figure 10. FTIR spectra of BA-ph/BPA22 system heat treated at various temperatures: (a) $160^{\circ} \mathrm{C}$, (b) $200^{\circ} \mathrm{C}$, (c) $240^{\circ} \mathrm{C}$ and (d) $280^{\circ} \mathrm{C}$

of $\mathrm{C}=\mathrm{N}$ and $\mathrm{C}-\mathrm{N}=$, respectively $[28,29]$. Additionally, the aforementioned characteristics and the low intensity absorption band at $2227 \mathrm{~cm}^{-1}$ corresponding to nitrile groups, indicated the high polymerization degree of nitrile groups at $160^{\circ} \mathrm{C}$. Moreover, the absorption intensity of nitrile groups decreased with increasing the content of BPA, suggesting the obvious catalysis. The wide and intensive absorption band at around $3364 \mathrm{~cm}^{-1}$ corresponding to the association state of hydroxyl were observed in all of the samples, reported previously $[15,16]$. The absorption peak at $2969 \mathrm{~cm}-1$ was assigned to the stretching vibration of $-\mathrm{CH}_{3}$ and no obvious changes were observed.

Figure 10 showed the FTIR spectra of BA-ph/BPA22 polymers obtained after being heated at 160, 200, 
240 and $280^{\circ} \mathrm{C}$, respectively. It was obvious that the characteristic absorption bands at $2227 \mathrm{~cm}^{-1}$ of the BA-ph/BPA22 polymers were evidently weakened, and the characteristic absorption band at 1620 and $1238 \mathrm{~cm}^{-1}$ increased with increasing the treated temperature. The intensive absorption band at $3364 \mathrm{~cm}^{-1}$ indicated the existence of association hydroxyl in BA-ph/BPA systems. With increasing the treatment temperature, it was obvious that the absorption intensity decreased slightly, suggesting that elevated temperature damaged the association hydrogen bond.

\subsection{Mechanical properties of BA-ph/BPA/GF composite laminates}

In the previous parts, copolymerizing behaviors and processability of BA-ph/BPA blends were investigated. These investigations can provide us with effective molding procedures to prepare GF-based BA$\mathrm{ph} / \mathrm{BPA}$ composite laminates. The mechanical properties of resulting BA-ph/BPA/GF composite laminates with various BPA contents were shown in Figures 11 and 12, in which properties of BA-ph/GF were also presented. Overall, for individual BA-ph/ BPA/GF composite laminate, the flexural properties were dramatically increased with the treated temperature increase and then decreased slightly. The flexural strength and flexural modulus of BA-ph/ GF composite laminate were increased with increasing the temperature and up to $542 \mathrm{MPa}$ and $25.8 \mathrm{GPa}$ at the completed polymerization temperature of $280^{\circ} \mathrm{C}$, respectively. BA-ph/BPA/GF21 composite laminate treated at $160^{\circ} \mathrm{C}$ exhibited high flexural strength of $632 \mathrm{MPa}$ and high flexural modulus of 23.6 GPa. Raising treatment temperatures, flexural strength of BA-ph/BPA/GF21 composite laminate increased to 786, 711 and $639 \mathrm{MPa}$ at 200, 240 and $280^{\circ} \mathrm{C}$, respectively. Analogously, the flexural strength of BA-ph/BPA/GF22 and BA-ph/BPA/ GF23 composite laminate increased to 737 and $753 \mathrm{MPa}$ at $200^{\circ} \mathrm{C}$ and decreased to 665 and $408 \mathrm{MPa}$ at $280^{\circ} \mathrm{C}$, respectively. The significant increase of flexural strength was attributed to the introducing of BPA which accelerated the polymerization of BA-ph resulting in an improved cross-linking degree. In addition, the association hydroxyl in the polymers proved by FTIR may be conducive to the improved flexural strength. However, the slight decrease of strength may be resulting from the volatilization of surplus BPA and the damage of

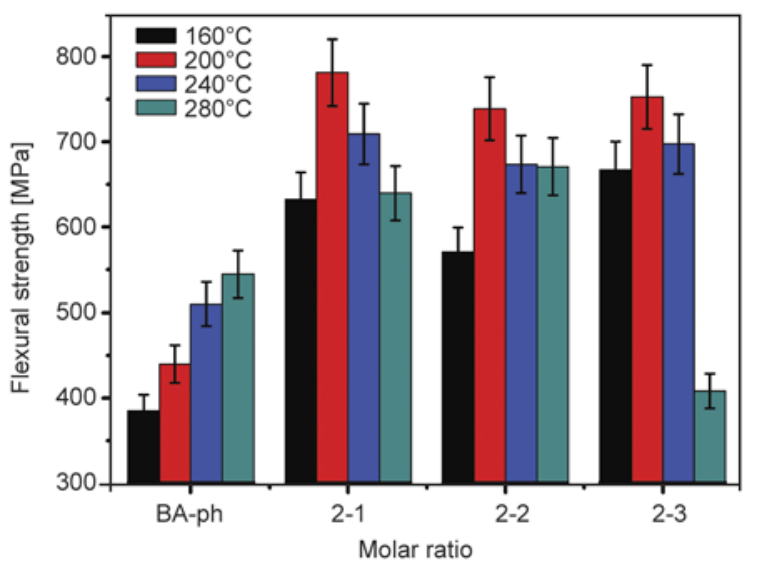

Figure 11. Flexural strength of BA-ph/BPA/GF system with various content of BPA

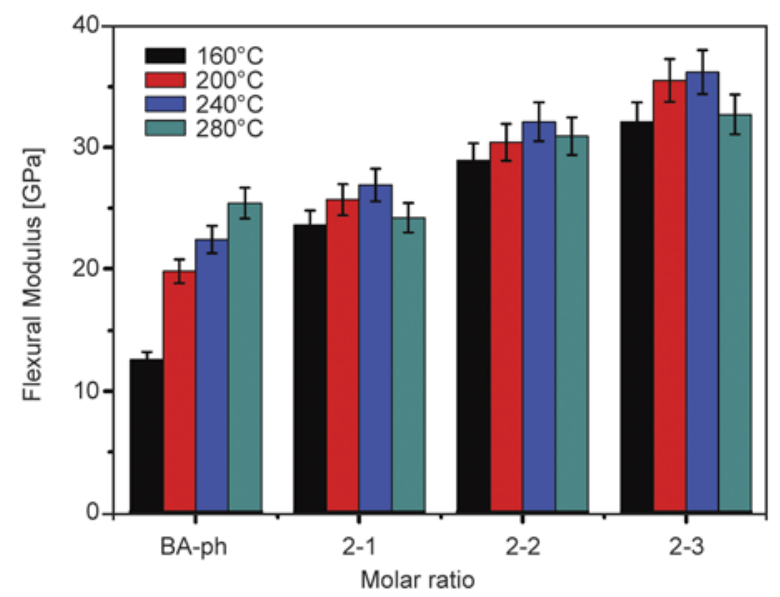

Figure 12. Flexural modulus of BA-ph/BPA/GF system with various content of BPA

hydrogen bond at elevated temperature, which was verified by the steep decline of the flexural strength for BA-ph/BPA/GF23 composite laminate. Additionally, the flexural modulus also showed regular increase or decrease with increasing or decreasing the BPA. In comparison with those of composite laminates reported previously, BA-ph/BPA/GF composite laminates which just underwent the heat treatment at $160^{\circ} \mathrm{C}$ for $4 \mathrm{~h}$ exhibited excellent mechanical properties. For thermosetting resin, long time curing and elevated temperature treatment were necessary. In the previous work, BA-ph/GF systems were treated for $11 \mathrm{~h}$ and the temperature was up to $280^{\circ} \mathrm{C}$ $[15,16]$. Phthalocyanine/GF systems were generally treated at $320^{\circ} \mathrm{C}$ for 2 or $4 \mathrm{~h}$ to obtain the laminates with good properties. For other thermosetting resins, such as epoxy resins, though did not require the treatment of high temperature and long time, the properties of EP/GF composite laminates were usually barely satisfactory. Yang et al. [30] have prepared EP/GF composite laminates with three kinds 
of GFs: plain weave fabric GF and biaxial or uniaxial stitched plain weave fabrics GF; and the corresponding flexural strengths of resulted EP/GF composite laminates were 370,233 and $326 \mathrm{MPa}$ with fiber volume of 56,56 and $57 \%$, respectively. Mouritz et al. [31] also reported that EP/GF composite laminates exhibited a relatively low mechanical performance with the flexural strength of $212 \mathrm{MPa}$ and flexural modulus of $12.9 \mathrm{GPa}$, with the fiber volume of $34 \%$.

Generally, mechanical properties of polymer/GF composite laminates depended on the properties of each primary component, the nature of the interface, and the locus of filler-matrix interaction between the matrix resins and GFs [32]. In our BA-ph/BPA/ GF systems, the good mechanical properties could be attributed to multiple factors. These mechanical properties are, on the one hand, attributed to primary component of GF and matrices themselves, while BA-ph was also traded for their good mechanical performances. On the other hand, the existence of association hydrogen bond which resulted from the polymerization of BA-ph/BPA blends was also a key factor. Furthermore, the polymerization of the matrices was significantly catalyzed by BPA, thus, the mechanical properties can be attributed to the highly crosslinked matrices. The exothermic enthalpy of the composites with various BPA and treated at various temperatures were summarized in Table 2. Results indicated that the conversion of oxazine rings and nitrile groups increased with increasing BPA or temperature, confirming the high crosslinking degree and the improved mechanical properties.

\subsection{Thermal stabilities of the BA-ph/BPA/GF composite laminates}

The thermal decomposition of the BA-ph/BPA/GF composite laminates was also examined by TGA (Figure 13 and 14) and the main results were summarized in Table 3 and 4, in which the initial degradation temperature $\left(T_{\mathrm{i}}\right)$, the temperatures at weight loss of $5 \%\left(T_{5 \%}\right)$ and $10 \%\left(T_{10 \%}\right)$ were displayed. Overall, thermal stabilities of BA-ph/BPA/GF com-

Table 2. Exothermic enthalpy of various BA-ph/BPA composites heated treated at various temperatures

\begin{tabular}{|l|c|c|c|c|}
\hline & $\mathbf{1 6 0}^{\circ} \mathbf{C}$ & $\mathbf{2 0 0}^{\circ} \mathbf{C}$ & $\mathbf{2 4 0}^{\circ} \mathbf{C}$ & $\mathbf{2 8 0}^{\circ} \mathbf{C}$ \\
\hline BA-ph-BPA21 & 25.8 & 10.7 & 8.2 & 7.2 \\
\hline BA-ph-BPA22 & 19.3 & 8.1 & 6.2 & 5.9 \\
\hline BA-ph-BPA23 & 16.5 & 6.9 & 4.0 & 3.2 \\
\hline
\end{tabular}

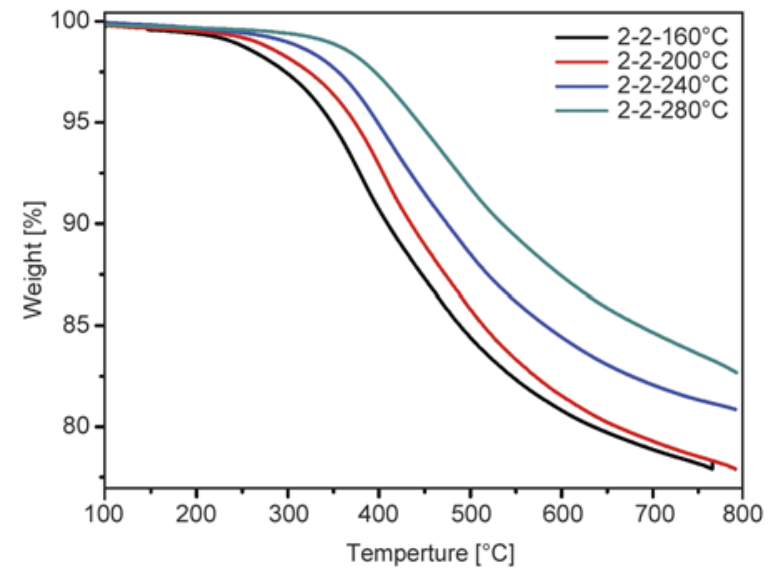

Figure 13. TGA curves of BA-ph/BPA22 system heat treated at various temperatures in nitrogen

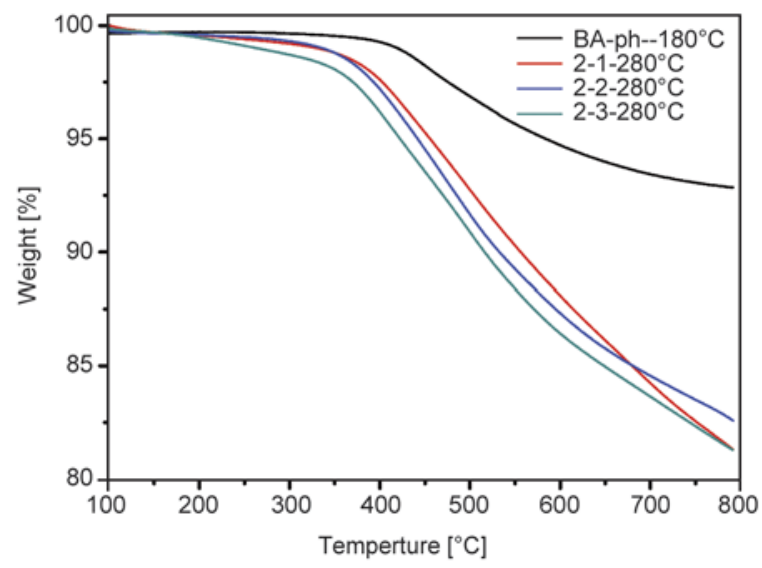

Figure 14. TGA curves of BA-ph/BPA system with various content of BPA heat treated at $280^{\circ} \mathrm{C}$

posites in $\mathrm{N}_{2}$ increased with raising the treatment temperature, attributed to the thermally induced polymerization and improved cross-linking density. Additionally, the catalysis of BPA was conducive to the further polymerization of BA-ph. Due to the volatilization of BPA at elevated temperature, the

Table 3. Thermal stabilities of BA-ph/BPA/GF22 laminates heated at various temperatures

\begin{tabular}{|l|c|c|c|}
\hline \multicolumn{1}{|c|}{ Samples } & $\mathbf{T}_{\mathbf{i}}$ & $\mathbf{T}_{\mathbf{5} \%}$ & $\mathbf{T}_{\mathbf{1 0} \%}$ \\
\hline $160^{\circ} \mathrm{C}$ & 300.6 & 365.2 & 444.2 \\
\hline $200^{\circ} \mathrm{C}$ & 321.4 & 372.8 & 435.2 \\
\hline $240^{\circ} \mathrm{C}$ & 339.7 & 397.2 & 474.2 \\
\hline $280^{\circ} \mathrm{C}$ & 364.9 & 445.5 & 537.7 \\
\hline
\end{tabular}

Table 4. Thermal stabilities of BA-ph/BPA/GF systems with various content of BPA heated at $280^{\circ} \mathrm{C}$

\begin{tabular}{|l|c|c|c|}
\hline \multicolumn{1}{|c|}{ Samples } & $\mathbf{T}_{\mathbf{i}}$ & $\mathbf{T}_{\mathbf{5 \%}}$ & $\mathbf{T}_{\mathbf{1 0}} \mathbf{}$ \\
\hline BA-ph & 456.0 & 589.0 & - \\
\hline BA-ph-BPA21 & 365.8 & 452.6 & 553.2 \\
\hline BA-ph-BPA22 & 364.9 & 445.5 & 537.7 \\
\hline BA-ph-BPA23 & 352.5 & 422.8 & 516.7 \\
\hline
\end{tabular}


further improvement of thermal stabilities was restricted by the content of BPA. Nevertheless, all BA-ph/BPA/GF composites could stand high $T_{10 \%}$ up to $510^{\circ} \mathrm{C}$ in $\mathrm{N}_{2}$. Compared with other state-ofthe-art thermosetting composite laminates, the BA$\mathrm{ph} / \mathrm{BPA} / \mathrm{GF}$ composite laminates exhibited excellent thermal stabilities. The phthalonitrile-based composites or laminates [26, 27], by comparison, showed as high $T_{\mathrm{i}}$ and $T_{5 \%}$ as BA-ph/BPA/GF systems. However, these composites have to be cured at elevated temperatures (over $350^{\circ} \mathrm{C}$ ) for a very long time ( $24 \mathrm{~h}$ or even more), which would be hard in the practical processing. The thermosetting polyimide-based composite laminates, on the other hand, were durable for a long time at $343^{\circ} \mathrm{C}$, but these laminates showed relatively low mechanical properties (flexural strength: $345 \mathrm{MPa}$; flexural modulus: 20.7G Pa) compared with BA-ph/BPA/GF systems (flexural strength: $781 \mathrm{MPa}$; flexural modulus: $23 \mathrm{GPa}$ ). The other laminates did not maintain the same degree of thermal stability [34] as BA-ph/ $\mathrm{BPA} / \mathrm{GF}$ systems. Meanwhile, the high-temperature machining increased the difficulty of processing and limited their potential applications.

\subsection{Dynamic thermomechanical analysis of the BA-ph/BPA/GF composite laminates}

In the previous parts, mechanical properties and thermal stabilities of BA-ph/BPA/GF laminates were investigated. Results indicated that the laminates shown outstanding mechanical properties treated at $200^{\circ} \mathrm{C}$, suggesting the considerably high cross-linking. Dynamic mechanical studies were conducted to evaluate the changes in the sample modulus as a function of temperature and determinate the $T_{\mathrm{g}}$ of the polymers after being treated at $200^{\circ} \mathrm{C}$. From these studies, storage modulus and tan delta plots generated on BA-ph/BPA/GF polymers versus temperature were presented in Figure 15 and 16, respectively, and the results of $T_{\mathrm{g}}$ were exhibited in Table 5 . In Figure 15, the modulus for BA-ph/BPA/GF22 changed from 32500 to $5000 \mathrm{MPa}$ when heated from 50 to $400^{\circ} \mathrm{C}$. The initial modulus of BA-ph/ BPA/GF22 and BA-ph/BPA/GF23 were approximate $(32280 \mathrm{MPa}$ and $30570 \mathrm{MPa})$ and higher than that of BA-ph/BPA/GF21 (26580 MPa), indicating the high cross-linking density of the laminates. For all of the samples, the decline of modulus was segmented, the first large modulus changes were observed at about $180 \sim 250^{\circ} \mathrm{C}$ and the second were

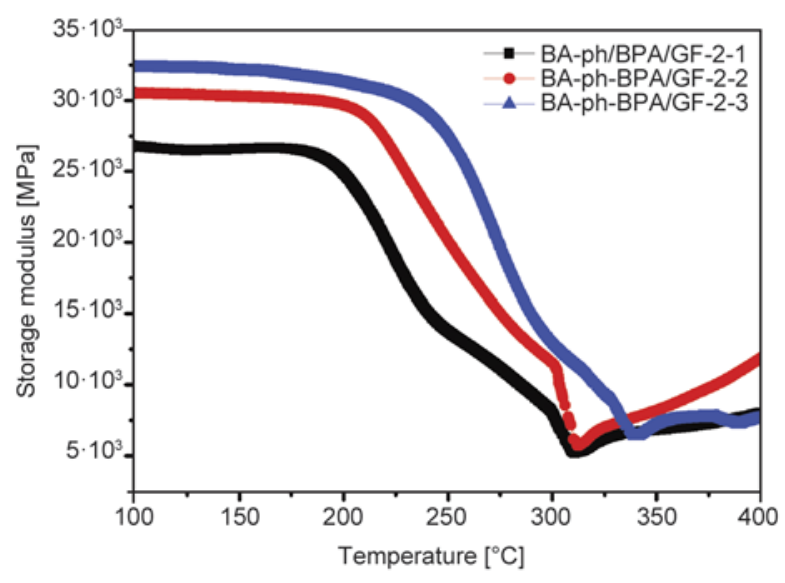

Figure 15. Storage modulus $\left(G^{\prime}\right)$ of BA-ph/BPA/GF system with various content of BPA

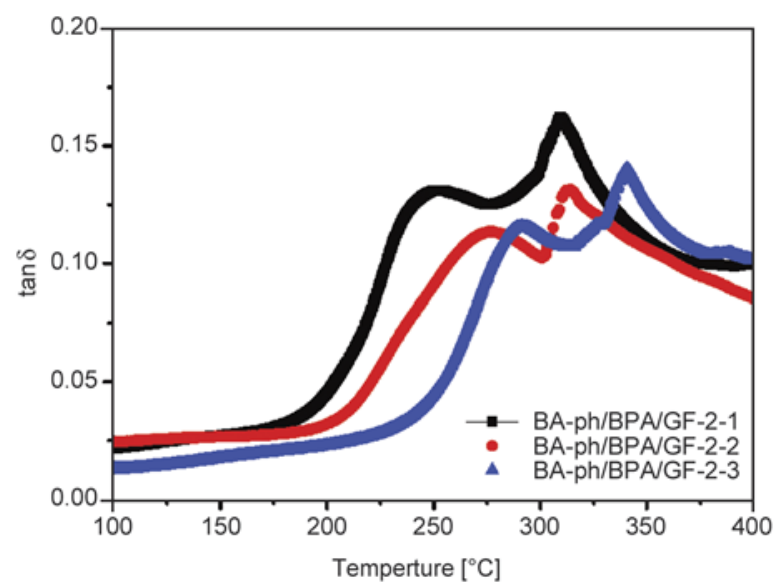

Figure 16. Damping factor $(\tan \delta)$ of BA-ph/BPA/GF system with various content of BPA

Table 5. Glass transition temperature of BA-ph/BPA/GF laminates heated $200^{\circ} \mathrm{C}$

\begin{tabular}{|l|c|c|}
\hline \multicolumn{1}{|c|}{ Samples } & $\begin{array}{c}\mathbf{T}_{\mathbf{g}_{1}} \\
{\left[{ }^{\circ} \mathbf{C}\right]}\end{array}$ & $\begin{array}{c}\mathbf{T}_{\mathbf{g}_{\mathbf{2}}} \\
{\left[{ }^{\circ}{ } \mathbf{C}\right]}\end{array}$ \\
\hline BA-ph/GF & - & 287 \\
\hline BA-ph/BPA/GF21 & 248 & 311 \\
\hline BA-ph/BPA/GF22 & 277 & 314 \\
\hline BA-ph/BPA/GF23 & 293 & 342 \\
\hline
\end{tabular}

about $250 \sim 350^{\circ} \mathrm{C}$. The data showed that the transformation temperature range increased with the increasing of BPA, attributed to the increased crosslinking density. The sectionalized decline of modulus suggested the microphase separation which resulted from the out-of-step polymerization of oxazine rings and nitrile groups at the presence of BPA.

The $T_{\mathrm{g}}$ was obtained from the maximum of $\tan \delta$ in a plot of $\tan \delta$ versus temperature. As noted in Figure 16, two obvious relaxation peaks were observed in each plot. The tan delta peaks $\left(200 \sim 300^{\circ} \mathrm{C}\right)$ of all BA-ph/BPA/GF were attributed to the Mannich 
bridge structures generated by ring-opening of oxazine rings catalyzed by BPA. On heating to $400^{\circ} \mathrm{C}$, the tan delta peaks occurred at the range of $300 \sim 370^{\circ} \mathrm{C}$, which was ascribed to the relaxation of aromatic heterocycte produced by the ring-forming polymerization of nitrile groups. Obviously, both the relaxation peaks shifted to higher temperature with increasing the content of BPA. Meanwhile, the space of the double peaks decreased with the content of BPA increasing. One possible explanation of these results was that the cross-linking degree of both oxazine rings and nitrile groups had been improved by the assistance of BPA, affording a reaction-induced microphase separation. As was well known, the $T_{\mathrm{g}}$ of polymers depends on the rigidity of the molecular chains and the cross-linking degree [35-40]. It can be seen in Table 5 that the $T_{\mathrm{g}_{1}}$ of the samples were up to $240^{\circ} \mathrm{C}$, which were superior to the traditional epoxy, phenolics and polybenzoxazines resin [36-40]. The $T_{\mathrm{g} 2}$ of the samples were up to $340^{\circ} \mathrm{C}$, which were comparable to that of phthalonitrile-based polymers cured at elevated temperature with longer time $[2,7,8]$. Also, a semi empirical equation has been used for calculating cross-link density of highly cross-linked systems $[41,42]$ shown in Equation (1):

$\log _{10} G^{\prime}=7+X_{\text {density }}$

where $G^{\prime}$ is the storage modulus of the cured blends in the rubbery plateau region in dynes $/ \mathrm{cm}^{2}$ above $T_{\mathrm{g}}$ (i.e. $T_{\mathrm{g}}+40^{\circ} \mathrm{C}$ ), $X_{\text {density }}$ is the cross-link density of the polymers. According to the equation, the crosslinking density of various BA-ph/BPA polymers was presented in Table 6 . It can be seen that all of the polymers exhibited high crosslinking degree (12000 13000 mol/ $\mathrm{m}^{3}$ ) which may confirm the good mechanical properties and glass transition temperatures. Besides, the increase of mechanical properties and glass transition temperatures can also be attributed to the high crosslinking degree. The outstanding $T_{\mathrm{g}}$ was mainly attributed to the high crosslinking degree of ring-opening polymerization of benzoxazine and heterocyclization of nitrile groups, which greatly limited the motion of the molecular chains.

\subsection{Phase morphology of the BA-ph/BPA composite}

SEM images of BA-ph/BPA22 polymers heat treated at various temperatures were presented in Figure 17. The images showed the evolution of the phase morphology as the cure advanced for BA-ph/BPA22 composites. After being treated at $160^{\circ} \mathrm{C}$, the reaction (ring-opening polymerization and formation of interlinked network) leads to a homogeneous phase (Figure 17a). As the temperature was raised, formation of homopolymer of phthalocyanine occurs parallel to linked network formation of polybenzoxaine. Minor tendency for phase separation is observed at this stage (Figure 17b and 17c). Spherical nodules are visible, which can be ascribed to the phthalocyanine rings dispersed in polybenzoxazine linked network. With increasing the temperature, the severity of phase separation is diminished because of the formation of inter linked network as the major phase (Figure 17d).

\section{Conclusions}

Copolymerization behaviors and processability of BA-ph/BPA systems were investigated. The structures of the polymers were confirmed and the possible curing reactions were discussed. Results demonstrated that the polymerization of the BA-ph/BPA blends were representative double-stage curing model. The components of the polymers depended on the relative content of BA-ph and BPA. The results of processability indicated polymerization of BA$\mathrm{ph} / \mathrm{BPA}$ blends was progressing in the ranges from 160 to $200^{\circ} \mathrm{C}$ and the polymerization of nitrile groups can be reduced to $160^{\circ} \mathrm{C}$. The GF-filled BA-ph/ BPA composite laminates were prepared and their mechanical and thermal properties were investigated. The flexural strength of BA-ph/BPA/GF composites was $789 \mathrm{MPa}$, which was superior to that of BA-ph/GF composites (542 MPa), although the modulus (23.6 GPa) decreased in compared with that of BA-ph/GF composites (25.8 GPa). Such mechani-

Table 6. Crosslinking density of BA-Ph/BPA polymers with various content of BPA

\begin{tabular}{|l|c|c|c|}
\hline \multicolumn{1}{|c|}{ Samples } & $\begin{array}{c}\mathbf{T}_{\mathbf{g}} \\
{\left[{ }^{\circ} \mathbf{C}\right]}\end{array}$ & $\begin{array}{c}\text { Glass modulus at ambient temperature } \\
{[\mathbf{G P a}]}\end{array}$ & $\begin{array}{c}\text { Crosslink density } \\
{\left[\mathbf{m o l}_{\mathbf{m}} / \mathbf{m}^{\mathbf{3}}\right]}\end{array}$ \\
\hline BA-ph/BPA/GF-21 & 311 & 26.5 & 12700 \\
\hline BA-ph/BPA/GF-22 & 314 & 30.6 & 13380 \\
\hline BA-ph/BPA/GF-23 & 342 & 32.3 & 13300 \\
\hline
\end{tabular}




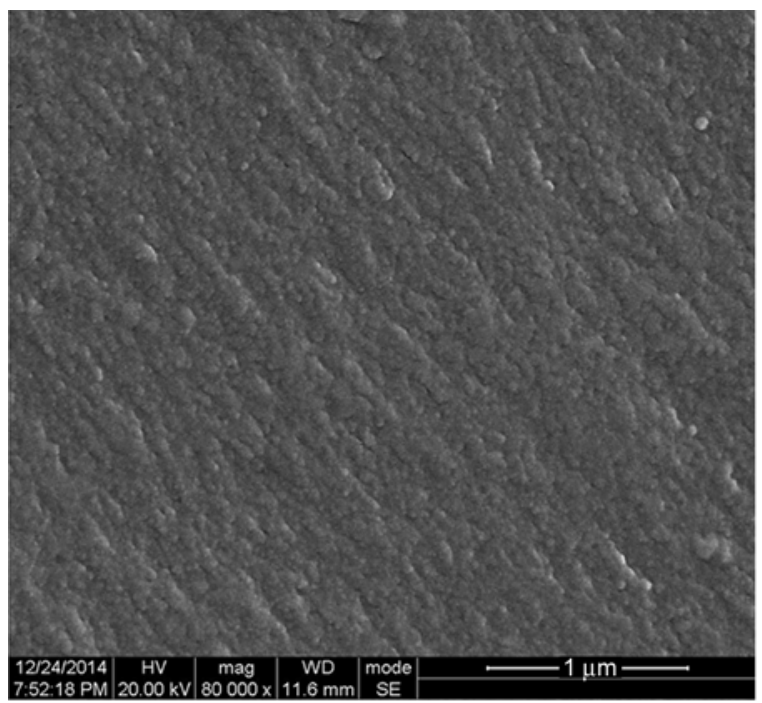

a)

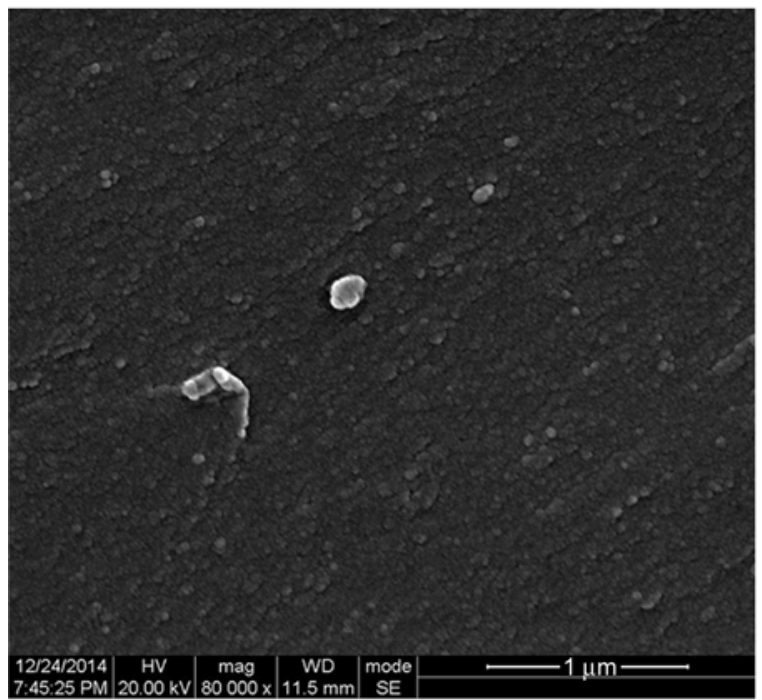

c)

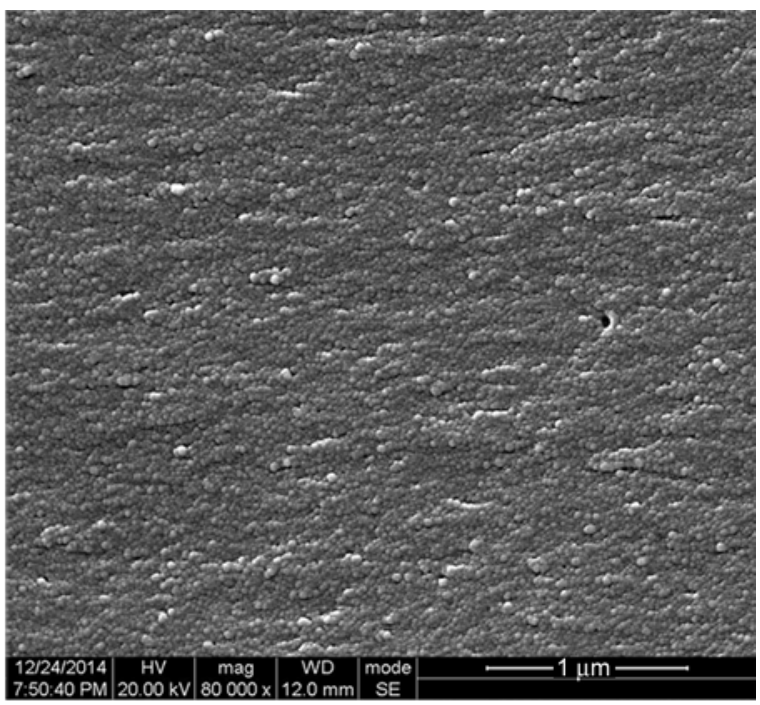

b)

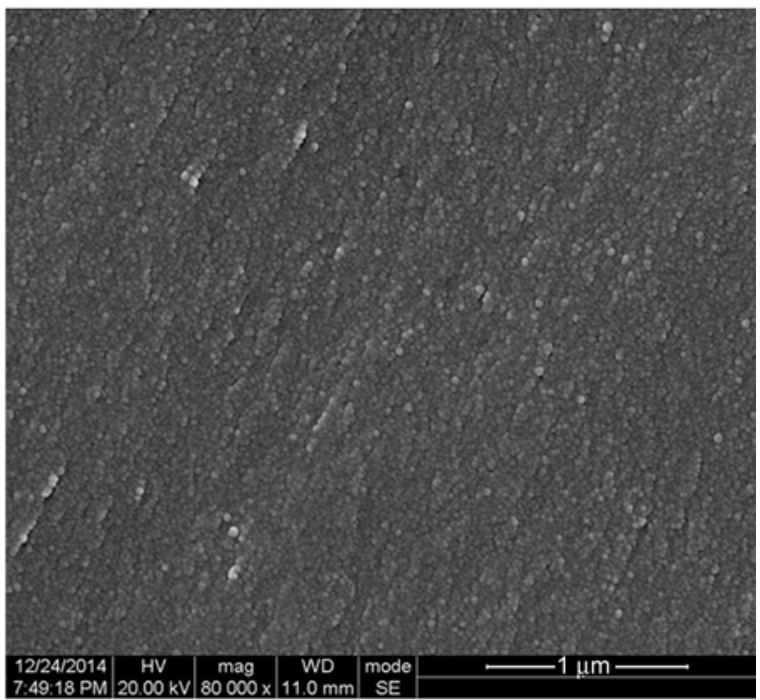

d)

Figure 17. SEM images of BA-ph/BPA22 composites heat treated at various temperatures: (a) $160^{\circ} \mathrm{C}$, (b) $200^{\circ} \mathrm{C}$, (c) $240^{\circ} \mathrm{C}$ and (d) $280^{\circ} \mathrm{C}$

cal enhancements can be attributed to the catalysis of BPA on the matrices and the abundant hydrogen bond. Additionally, for BA-ph/BPA/GF laminates, two $T_{\mathrm{g}}$ 's were observed, suggesting the microphase separation of BA-ph/BPA polymers because of the out-of-step polymerization of oxazine rings and nitrile groups, which was also confirmed by the SEM images. Thermal stabilities revealed that all of the BA-ph/BPA/GF composites could stand high $T_{10 \%}$ up to $510^{\circ} \mathrm{C}$ in $\mathrm{N}_{2}$. These characteristics could enable the BA-ph/BPA/GF composites to find uses under some critical circumstances with requirements of excellent mechanical properties and high temperature resistance. Moreover, an idea has been suggested in this work to prepare a semi-IPN type polymer.

\section{Acknowledgements}

The authors wish to thank for financial support of this work from the National Natural Science Foundation of China (No. 51173021, 51373028) and '863' National Major Program of High Technology (2012AA03A212).

\section{References}

[1] Nagai A., Eguchi S., Ishii T., Ogata M., Nishi K.: Encapsulating material design of epoxy molding compounds for high reliability semiconductor packaging. Polymer News, 21, 44-52 (1996).

[2] Guo H., Lei Y., Zhao X., Yang X., Zhao R., Liu X.: Curing behaviors and properties of novolac/bisphthalonitrile blends. Journal of Applied Polymer Science, 125, 649-656 (2012).

DOI: $\underline{10.1002 / a p p .36335}$ 
[3] Jin L., Agag T., Ishida H.: Bis(benzoxazine-maleimide)s as a novel class of high performance resin: Synthesis and properties. European Polymer Journal, 46, 354-363 (2010). DOI: $10.1016 /$ j.eurpolymj.2009.09.013

[4] Takeichi T., Kawauchi T., Agag T.: High performance polybenzoxazines as a novel type of phenolic resin. Polymer Journal, 40, 1121-1131 (2008).

DOI: 10.1295/polymj.PJ2008072

[5] Laskoski M., Dominguez D. D., Keller T. M.: Synthesis and properties of a bisphenol A based phthalonitrile resin. Journal of Polymer Science Part A: Polymer Chemistry, 43, 4136-4143 (2005).

DOI: $10.1002 /$ pola.20901

[6] Dominguez D. D., Keller T. M.: Low-melting phthalonitrile oligomers: Preparation, polymerization and polymer properties. High Performance Polymer, 18, 283304 (2006).

DOI: $10.1177 / 0954008306060143$

[7] Keller T. M., Dominguez D. D.: High temperature resorcinol-based phthalonitrile polymer. Polymer, 46, 4614 4618 (2005).

DOI: $10.1016 /$ j.polymer.2005.03.068

[8] Dominguez D. D., Keller T. M.: Properties of phthalonitrile monomer blends and thermosetting phthalonitrile copolymers. Polymer, 48, 91-97 (2007).

DOI: $10.1016 /$ j.polymer.2006.11.003

[9] Laskoski M., Keller T. M., Qadri S. B.: Direct conversion of highly aromatic phthalonitrile thermosetting resins into carbon nanotube containing solids. Polymer, 48, 7484-7489 (2007).

DOI: 10.1016/j.polymer.2007.11.003

[10] Laskoski M., Dominguez D. D., Keller T. M.: Synthesis and properties of aromatic ether phosphine oxide containing oligomeric phthalonitrile resins with improved oxidative stability. Polymer, 48, 6234-6240 (2007)

DOI: $10.1016 /$ j.polymer.2007.08.028

[11] Cao G. P., Chen W. J., Wei J. J., Li W. T., Liu X. B.: Synthesis and characterization of a novel bisphthalonitrile containing benzoxazine. Express Polymer Letters, 1, 512-518 (2007).

DOI: $10.3144 /$ expresspolymlett.2007.73

[12] Sumner M. J., Sankarapandian M., McGrath J. E., Riffle J. S., Sorathia U.: Flame retardant novolac-bisphthalonitrile structural thermosets. Polymer, 43, 50695076 (2002)

DOI: $10.1016 / \mathrm{S} 0032-3861(02) 00354-3$

[13] Zeng K., Hong H., Zhou S. H., Wu D. M., Miao P., Huang Z., Yang G.: A new soluble aramide with pendant phthalonitrile units and polymer property enhancement by nitrile cure reactions. Polymer, 50, 50025006 (2009).

DOI: $10.1016 /$ j.polymer.2009.08.033
[14] Xu M., Yang X., Zhao R., Liu X.: Copolymerizing behavior and processability of benzoxazine/epoxy systems and their applications for glass fiber composite laminates. Journal of Applied Polymer Science, 128, 1176-1184 (2013). DOI: 10.1002/app.38422

[15] Xu M., Hu J., Zou X., Liu M., Dong S., Zou Y., Liu X.: Mechanical and thermal enhancements of benzoxazine-based GF composite laminated by in situ reaction with carboxyl functionalized CNTs. Journal of Applied Polymer Science, 129, 2629-2637 (2013). DOI: 10.1002/app.38988

[16] Xu M. Z., Liu M. D., Dong S. H., Qiu G. Y., Liu X. B.: Active diluents effects of 4-nonylphenoxy-1, 2-dinitrilbenzene on phthalonitrile containing benzoxazine and their copolymerization behaviors. Express Polymer Letters, 7, 984-995 (2013). DOI: 10.3144 /expresspolymlett.2013.97

[17] McDonagh A. F., Smith H. E.: Ring-chain tautomerism of derivatives of o-hydroxybenzylamine with aldehydes and ketones. The nuclear magnetic resonance spectra of immonium ions. Journal of Organic Chemistry, 33, 8-12 (1968).

DOI: $10.1021 /$ jo0 $01265 \mathrm{a} 002$

[18] Ishida H., Ohba S.: Synthesis and characterization of maleimide and norbornene functionalized benzoxazines. Polymer, 46, 5588-5595 (2005). DOI: $10.1016 /$ j.polymer.2005.04.080

[19] Keller T. M., Griffith J. R.: Polyphthalocyanine resins. U.S. Patent 4234712 A, USA (1980).

[20] Keller T. M.: Phenolic-cured phthalonitrile resins. U.S. Patent 4410676 A, USA (1983).

[21] Burke W. J., Mortenson Glennie E. L., Weatherbee C.: Condensation of halophenols with formaldehyde and primary amines. Journal of Organic Chemistry, 29, 909-912 (1964).

DOI: $10.1021 / \mathrm{jo0} 1027 \mathrm{a} 038$

[22] Burke W. J., Bishop J. L., Mortensen Glennie E. L., Bauer W. N.: A new aminoalkylation reaction. condensation of phenols with dihydro-1,3-aroxazines. Journal of Organic Chemistry, 30, 3423-3427 (1965).

DOI: $10.1021 /$ jo01021a037

[23] Riess G., Schwob J. M., Guth G., Roche M., Laude B.: Ring opening polymerization of benzoxazines - A new route to phenolic resins. Advances in Polymer Synthesis, Polymer Science and Technology, 31, 27-39 (1985). DOI: $10.1007 / 978-1-4613-2121-7 \_2$

[24] Dominguez D. D., Keller T. M.: Phthalonitrile-epoxy blends: Cure behavior and copolymer properties. Journal of Applied Polymer Science, 110, 2504-2515 (2008). DOI: 10.1002/app.28817

[25] Laza J. M., Vilas J. L., Mijangos F., Rodríguez M., León L. M.: Analysis of the crosslinking process of epoxy-phenolic mixtures by thermal scanning rheometry. Journal of Applied Polymer Science, 98, 818-824 (2005).

DOI: $10.1002 /$ app. 22106 
[26] Ning X., Ishida H.: Phenolic materials via ring-opening polymerization: Synthesis and characterization of bisphenol-A based benzoxazines and their polymers. Journal of Polymer Science Part A: Polymer Chemistry, 32, 1121-1129 (1994).

DOI: 10.1002/pola.1994.080320614

[27] Agag T., Takeichi T.: Novel benzoxazine monomers containing $p$-phenyl propargyl ether: Polymerization of monomers and properties of polybenzoxazines. Macromolecules, 34, 7257-7262 (2001)

DOI: $10.1021 / \mathrm{ma} 0107915$

[28] Young J-N., Chang T-C., Tsai S-C., Yang L., Yu S. J.: Preparation of a nonleaching, recoverable and recyclable palladium-complex catalyst for Heck coupling reactions by immobilization on Au nanoparticles. Journal of Catalysis, 272, 253-261 (2010) DOI: $10.1016 /$ j.jcat.2010.04.005

[29] Ogino C., Kanehira K., Sasai R., Sonezakai S., Shimizu N.: Recognition and effective degradation of $17 \beta-$ estradiol by anti-estradiol-antibody-immobilized $\mathrm{TiO}_{2}$ nanoparticles. Journal of Bioscience and Bioengineering, 104, 339-342 (2007)

DOI: $10.1263 / \mathrm{jbb} .104 .339$

[30] Yang B., Kozey V., Adanur S., Kumar S.: Bending, compression, and shear behavior of woven glass fiberepoxy composites. Composites Part B: Engineering, 31, 715-724 (2000). DOI: 10.1016/S1359-8368(99)00052-9

[31] Mouritz A. P., Mathys Z., Gardiner C. P.: Thermomechanical modelling the fire properties of fibre-polymer composites. Composites Part B: Engineering, 35, 467-474 (2004).

DOI: 10.1016/j.compositesb.2003.09.005

[32] Prashantha K., Soulestin J., Lacrampe M. F., Claes M., Dupin G., Krawczak P.: Multi-walled carbon nanotube filled polypropylene nanocomposites based on masterbatch route: Improvement of dispersion and mechanical properties through PP-g-MA addition. Express Polymer Letters, 2, 735-745 (2008). DOI: $10.3144 /$ expresspolymlett.2008.87

[33] Keller T. M.: Phthalonitrile-based high temperature resin. Journal of Polymer Science Part A: Polymer Chemistry, 26, 3199-3212 (1988). DOI: $10.1002 /$ pola.1988.080261207
[34] Kuznetsov A. A., Semenova G. K.: Perspective thermally stable thermoset binders for polymer composite materials. Russian Journal of General Chemistry, 80, 2170-2180 (2010). DOI: $10.1134 / \mathrm{S} 1070363210100464$

[35] Chow T. S.: Molecular interpretation of the glass transition temperature of polymer-diluent systems. Macromolecules, 13, 362-364 (1980)

DOI: $10.1021 / \mathrm{ma} 60074 \mathrm{a} 029$

[36] Hancock B. C., Zografi G.: The relationship between the glass transition temperature and the water content of amorphous pharmaceutical solids. Pharmaceutical Research, 11, 471-477 (1994).

DOI: 10.1023/A:1018941810744

[37] Forrest J. A., Dalnoki-Veress K., Stevens J. R., Dutcher J. R.: Effect of free surfaces on the glass transition temperature of thin polymer films. Physical Review Letters, 7, 2002-2005 (1996).

DOI: 10.1103/PhysRevLett.77.2002

[38] Forrest J. A., Dalnoki-Veress K., Dutcher J. R.: Interface and chain confinement effects on the glass transition temperature of thin polymer films. Physical Review E, 56, 5705-5716 (1997). DOI: 10.1103/PhysRevE.56.5705

[39] Allaoui A., El Bounia N.: How carbon nanotubes affect the cure kinetics and glass transition temperature of their epoxy composites? - A review. Express Polymer Letters, 3, 588-594 (2009).

DOI: 10.3144 /expresspolymlett.2009.73

[40] Kimura H., Ohtsuka K., Matsumoto A.: Curing reaction of bisphenol-A based benzoxazine with cyanate ester resin and the properties of the cured thermosetting resin. Express Polymer Letters, 5, 1113-1122 (2011).

DOI: 10.3144/expresspolymlett.2011.108

[41] Ward I. M., Hadley D. W.: An introduction to the mechanical properties of solid polymers. Wiley, New York (1993).

[42] Santhosh Kumar K. S., Reghunadhan Nair C. P., Ninan $\mathrm{K}$. N.: Investigations on the cure chemistry and polymer properties of benzoxazine-cyanate ester blends. European Polymer Journal, 45, 494-502 (2009) DOI: 10.1016/j.eurpolymj.2008.11.001 